\title{
Sediment Speciation from Dekin Groundwater at District of Dangbo (South Benin)
}

\author{
Abdoukarim Alassane1, Waris Kéwouyèmi Chouti ${ }^{1,2 *}$, Hermione Adeke1, Jechonias Hounkpe3, \\ Daouda Mama1, Moussa Boukari1
}

${ }^{1}$ Laboratory of Applied Hydrology, National Institute of Water (NIW), University of Abomey-Calavi, Cotonou, Benin

${ }^{2}$ Laboratory of Inorganic Chemistry and Environment, Faculty of Sciences and Techniques (FAST), University of Abomey-Calavi, Benin

${ }^{3}$ Laboratory of Geology, Mines and Environment, Faculty of Sciences and Engineering, University of Abomey-Calavi, Benin

Email: aalassane@yahoo.fr, abdoukarim.alassane@ine.uac.bj, ‘warischouti@yahoo.com,waris.chouti@uac.bj,

admir91@yahoo.com, jecolune2@yahoo.fr,mkdaouda@yahoo.fr, moussaboukari2003@yahoo.fr

How to cite this paper: Alassane, A., Chouti, W.K., Adeke, H., Hounkpe, J., Mama, D. and Boukari, M. (2018) Sediment Speciation from Dekin Groundwater at District of Dangbo (South Benin). Journal of Geoscience and Environment Protection, 6, 59-72.

https://doi.org/10.4236/gep.2018.610005

Received: September 5, 2018

Accepted: October 28, 2018

Published: October 31, 2018

Copyright $\odot 2018$ by authors and Scientific Research Publishing Inc. This work is licensed under the Creative Commons Attribution International License (CC BY 4.0).

http://creativecommons.org/licenses/by/4.0/

\begin{abstract}
The objective of this research is to determine the physicochemical elements contained in the groundwater and in the deposits originating from these waters of the Arrondissement of Dêkin, Commune of Dangbo in the South of Benin. Physical parameters were measured from the multi-parameter and the chemical parameters by reagent assays. The precipitate from the groundwater was studied by speciation. The different assays were carried out using the Hach Lange DR2800 Spectrophotometer. The data processing was done with different software including ArcGis 10.1, Diagram.Ink of Roland SIMLER and PHREEQC 2.17.4137. Strong mineralization of the deposit from the drilling water was indicated in these three elements: Copper $(220.1 \mathrm{mg} / \mathrm{kg})$, iron $(2528 \mathrm{mg} / \mathrm{kg})$ and zinc $(239.5 \mathrm{mg} / \mathrm{kg})$ whose contents are higher than the French guideline values for heavy metal content in sediments in $\mathrm{mg} / \mathrm{kg}$. The calculation of the Saturation Indices of the drilling water shows saturation with respect to Goethite and Hematite. All these results have led us to conclude that the high content of Metallic Trace Element (MTE) in the deposit and especially of the iron in the drilling water originates from the dissolution-precipitation of the aquifer rock.
\end{abstract}

\section{Keywords}

Metal Trace Element, Chemical Speciation, Groundwater, Geochemical Fraction, Dangbo, Benin

\section{Introduction}

Water is a limited natural resource and public property. It is essential to all the 
different aspects of life and health, constituting one of most important factors of sustainable development [1]. 663 million people have not access to a quality water and more than 2.4 billion people to an adequate cleansing; which is the main cause of waterborne diseases transmission [2]. The poor quality of water in East Africa, partly, causes several diseases and the high rate of infant mortality.

These last years, the international community is increasingly conscious of the gravity of the increasing situation of water requirements of populations of each country. With a stagnation, or a reduction, especially a depreciation of available water resources, this community organizes itself to lead humanity, to improve more its vision, to reconsider its position and to adopt more a responsible attitude with respect to the water resources.

Actually, faulty operation and inexistence of Drinkable Water provision's system led populations to resort directly to groundwater resulting from the captive and surface tablecloths [3]. The access of groundwater is difficult and is requested for the Drinkable Water provision. Therefore, they were object of several studies throughout the world [4] [5] [6].

The District of Dêkin is located in southern part of Benin, presently knows a problem involved the quality of their drink water coming from drillings.

In Dêkin, water collected from fountain, capted by the borehole of Hounhouè, always keeps its qualities colourless and odourless. However, this water lets appear, after a few hours of storage, deposits of reddish color predicting a deterioration of its quality. This also raises concerns about the quality of this water by the population. This population suspects it of containing too much pollutant because of the reddish color of the deposit.

The study of the physicochemical parameters of the waters and the various chemical forms, meaning the speciation of the trace elements in the deposits coming from the water of these supply works, appears essential to better understand the factors which control the abundance of these elements.

This work aims mainly to characterize the deposits from groundwater in Dêkin District - Dangbo City in southern Benin in order to suggest corrective measures to make them drinkable.

\section{Material and Methods}

It consisted in accessing the water drilling in Hounhouè's village and taking a sample of the groundwater. Figure 1 shows the location of Hounhouè's borehole in Dêkin District.

The drill hole of Hounhouè cross different lithological layers. These are from top to bottom: ocher-ocher silty level with bank of 0 to $7 \mathrm{~m}$, a thick layer of yellow clay interspersed with clayey altered gravel. The latter is followed successively by a level of fine sand of 36 to $38 \mathrm{~m}$, a layer of limestone of 38 to $44 \mathrm{~m}$ and gravel up to $50 \mathrm{~m}$. It follows a thick layer of $30 \mathrm{~m}$ of fine sand ranging from 50 to $80 \mathrm{~m}$ deep (corresponding to the Mio-pliocene layer). All this is shown in the next figure (Figure 2). 
Sample was with drawed in four cans of twenty-five-liter and two bottles of one-liter as part of this study. These cans and bottles were all previously washed and rinsed with distilled water in laboratory. From the laboratory and before the field work, $1 \mathrm{~mL}$ of nitric acid was injected into a bottle of one liter to lower the $\mathrm{pH}$. This neutralizes the effect of the oxides and hydroxides towards the anions, thus preventing the formation of deposit in water.

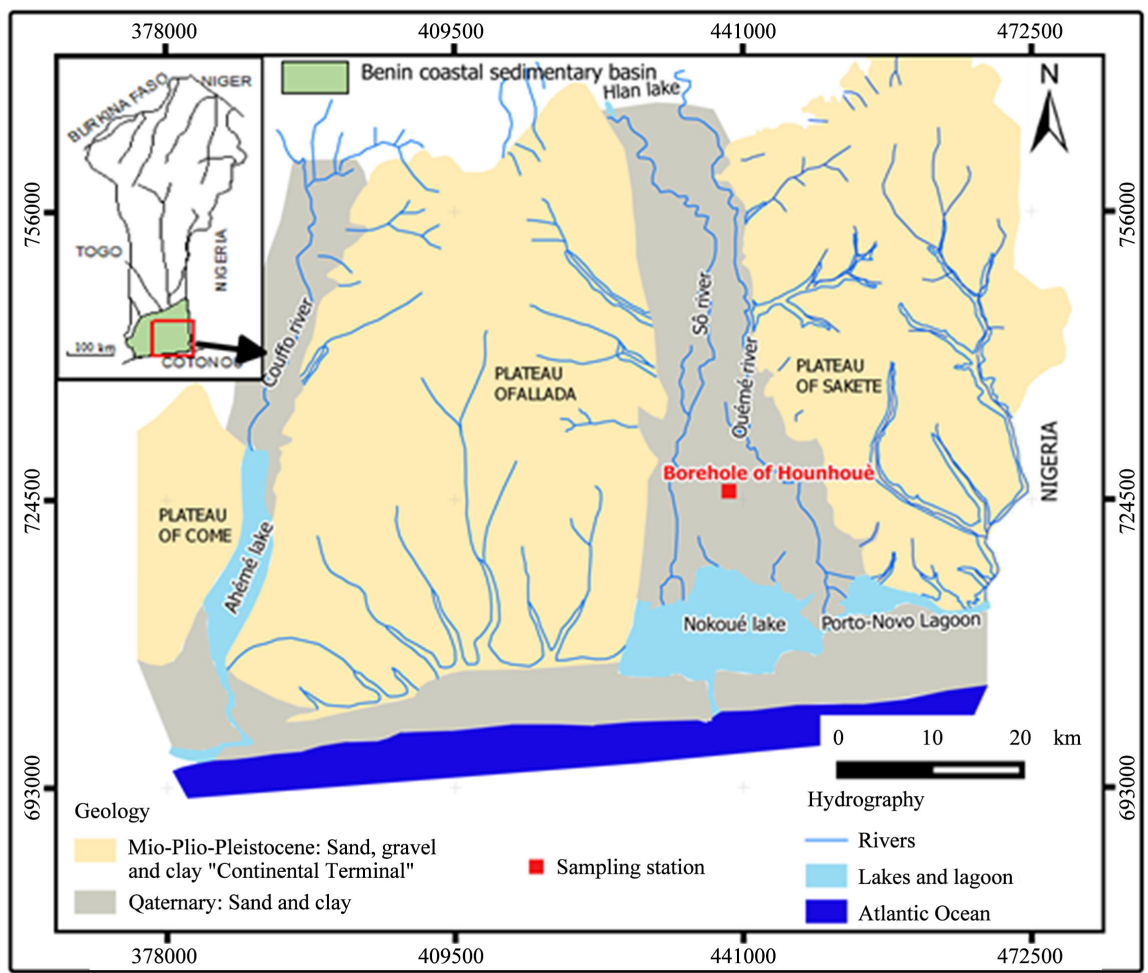

Figure 1. Location of Hounhouè's borehole in Dêkin District.

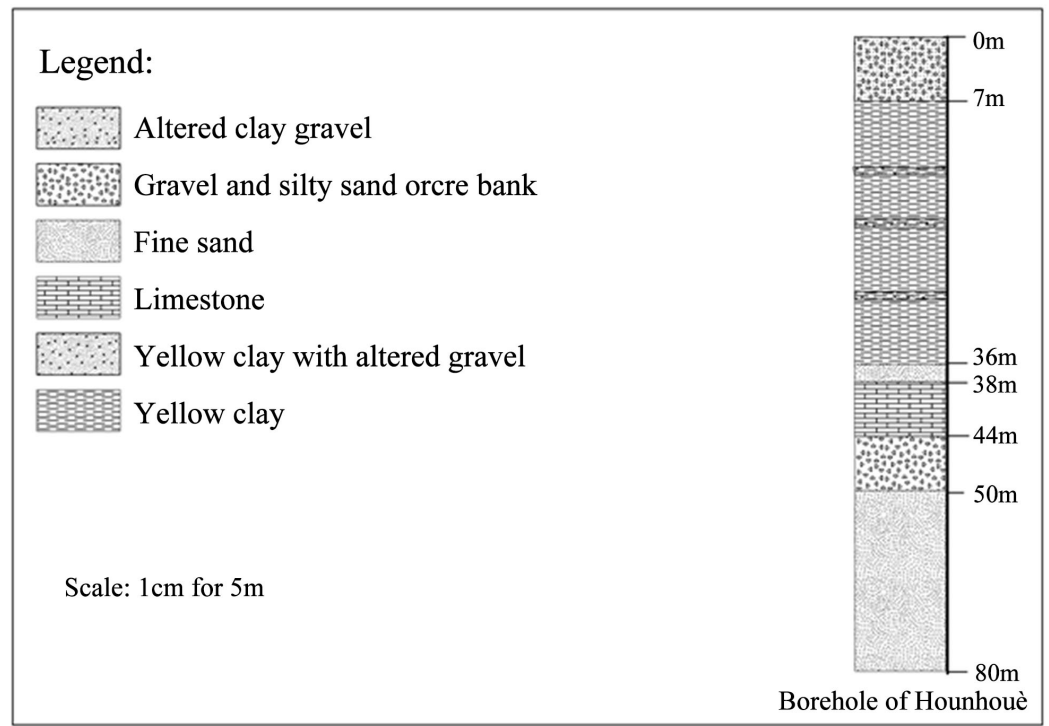

Figure 2. Lithological section of the drilling of Hounhouè. 
In practice, the flow tap should be opened maximum for 5 to 10 seconds then bring it back to an average flow for 2 minutes [7]. So, immediately on the ground, before the sampling, we left the water flowed first for about 5 to 10 seconds at maximum flow, then to bring back to an average flow for 2 minutes more to have chance to collect the water of the collected water, and not the one stored in the water tower.

The non-acidified sample bottle and the cans were again rinsed 3 times with water to be analyzed. They were subsequently filled with water without leaving any air bubbles. These flasks were finally hermetically sealed. The acidified one was used directly for sampling and did not require rinsing with water any more.

Back from the field, all samples were stored at the Laboratory of Applied Hydrology (LHA) of the National Institute of Water (NIW) at the University of Abomey-Calavi (UAC) where researches on the waters and deposits from these waters were conducted. The water bottle of one liter acidified was used for the analysis of cations such as $\mathrm{Ca}^{2+}, \mathrm{Mg}^{2+}, \mathrm{Na}^{+}, \mathrm{K}^{+}, \mathrm{NH}^{4+}$ in addition to metals (iron, copper and zinc). The other bottle was used to search for anions such as $\mathrm{Cl}^{-}$, $\mathrm{SO}_{4}^{2-}, \mathrm{NO}_{3}^{-}, \mathrm{NO}_{2}^{-}, \mathrm{PO}_{4}^{3-}$ and $\mathrm{F}^{-}$. These ions were all measured using the Hach Lange Spectrophotometer DR2800.

Water of the cans of twenty-five liters made it possible to collect the deposits resulting from water. These deposits were prepared before analysis. This phase is crucial and makes it possible to obtain a representative sample in which the concentration in pollutants is very close to that presents in the deposits. It includes decantation to collect mainly the deposit formed at the bottom of the containers, the drying in the open air or in the laboratory in order to eliminate the humidity and to avoid any deterioration before the mineralization and the sieving, a necessary step for the elimination of large solid fragments that are not usually considered as part of the deposit. After the phase of preparation of the deposits, the samples are subjected to the method of sequential extractions.

The analyses relating to the chemical speciation of iron, copper and zinc were carried out by the protocol of Tessier et al., 1979 [8]. Table 1 illustrates this protocol.

Table 1. Sequential extractions for $1.0 \mathrm{~g}$ sediment sample.

\begin{tabular}{|c|c|c|c|}
\hline Fraction & Reagents chemical & Volume (mL) & Time (h) \\
\hline Exchangeable & $1 \mathrm{M} \mathrm{MgCl}_{2}, \mathrm{pH}=7,20^{\circ} \mathrm{C}$, continuous agitation & 8 & 1 \\
\hline $\begin{array}{l}\text { Acid-soluble } \\
\qquad\left(\mathrm{CO}_{3}^{2-}\right)\end{array}$ & $\begin{array}{c}1 \mathrm{M} \mathrm{CH} \mathrm{COONa}_{3} \mathrm{CH}_{3} \mathrm{COOH}, \mathrm{pH} 5 \\
20^{\circ} \mathrm{C} \text {, continuous agitation }\end{array}$ & 8 & 5 \\
\hline $\begin{array}{l}\text { Reducible } \\
(\mathrm{Fe} ; \mathrm{Mn})\end{array}$ & $\begin{array}{c}0.04 \mathrm{M} \mathrm{NH}_{2} \mathrm{OH}, \mathrm{HCl}+25 \% \mathrm{CH}_{3} \mathrm{COOH} \\
95^{\circ} \mathrm{C} \text { intermittent agitation }\end{array}$ & 20 & 6 \\
\hline $\begin{array}{l}\text { Oxidizable } \\
\text { (M.O.) }\end{array}$ & $\begin{array}{c}30 \% \mathrm{H}_{2} \mathrm{O}_{2}, 0.02 \mathrm{M} \mathrm{HNO}_{3}, \mathrm{pH}=2,85^{\circ} \mathrm{C} \text {, Intermittent } \\
\text { agitation, } 3.2 \mathrm{M} \mathrm{CH}_{3} \mathrm{COONH}_{4},+20 \% \mathrm{HNO}_{3}\end{array}$ & $\begin{array}{l}5 \\
3 \\
5\end{array}$ & 0.5 \\
\hline Residual & $40 \% \mathrm{HF}+60 \% \mathrm{HClO}_{4}$ (Total mineralization) & 5 & à sec \\
\hline $\begin{array}{l}\text { Total content } \\
\text { in Metal }\end{array}$ & $40 \% \mathrm{HF}+60 \% \mathrm{HClO}_{4}$ (Total mineralization) & 10 & à sec \\
\hline
\end{tabular}




\section{Result}

The results obtained from the physical and chemical analyzes are showed in Figure 3 and Figure 4 below and relate to the anion and cation contents of the water from the Hounhouè borehole, district of Dêkin.

Figure 3 shows a high temperature value $\left(29.3^{\circ} \mathrm{C}\right)$ compared to the World Health Organisation (WHO) standard $\left(25^{\circ} \mathrm{C}\right)$ [2]. This could be explained by the influence of the ambient temperature on the water sampled and also by the geothermal gradient of the area [9].

The $\mathrm{pH}$ value (6.11) is lower than the normal range of WHO, and Benin $(6.5<$ $\mathrm{pH}<8.5)$. It is acid prone and qualifies water from drilling as aggressive.

Color parameter of the measured water is raised above the different standards. Due to the red coloring of the water, the presence of inorganic materials such as iron, copper and zinc is suspected. It could have a geological origin.

The Figure 5 shows the comparison between all these values.

We find high values of iron and ammonium ions compared to standards. The results have been represented on Figure 6 .

Figure 7 indicates that Hounhouè borehole's water in the District of Dêkin is supersaturated with respect to Goethite and Hematite. The other mineral phases show under saturation of the same water.

Figure 8 presents the results of the sequential extractions of iron.

This figure shows that the exchangeable fraction is the dominant one with $32 \%$ in the various extracts. Iron is therefore mainly adsorbed on the mineral surfaces by nonspecific bonds. However, the exchangeable fraction is the main factor impacting the behavior of iron in the water of Hounhouè drilling. It is the fraction presenting more risk for the water. In the same way, this fraction is followed by the acid-soluble fraction which the second fraction is presenting more risk.

Figure 9 presents the results from the sequential extractions of copper.

Most of the copper is found in the reducible fraction, which then admits a main bond with the oxides of iron, aluminum and manganese, which are weakly crystalline or amorphous. These elements therefore control the amount of copper in the water of the borehole.

Figure 10 presents the results from the sequential extractions of zinc.

Zinc is also found, like copper, strongly bound to iron oxides. Smaller bonds were revealed with respect to carbonates and organic matter. Zinc is also found in the exchangeable fraction but does not exist in the residual fraction.

It results thus from our study that the precipitate obtained is due to the strong presence of iron in waters, which, by oxidizing, retains copper and zinc in the deposit.

Figure 11 gathers the values of the results of chemical analyses carried out on the deposits. It shows a superiority of the values measured compared to those of the French guide. This implies the pollution of this water of drilling by ions strong mineralization. It deserves to be treated to fulfill the necessary requirements. 


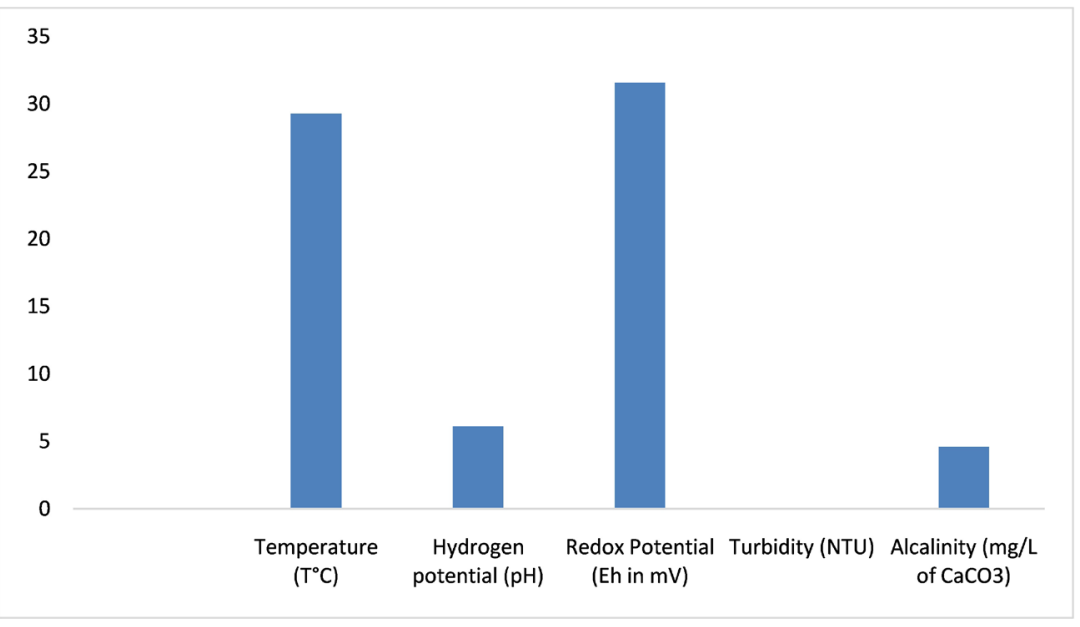

Figure 3. Physicochemical parameters of water from the Hounhouè.

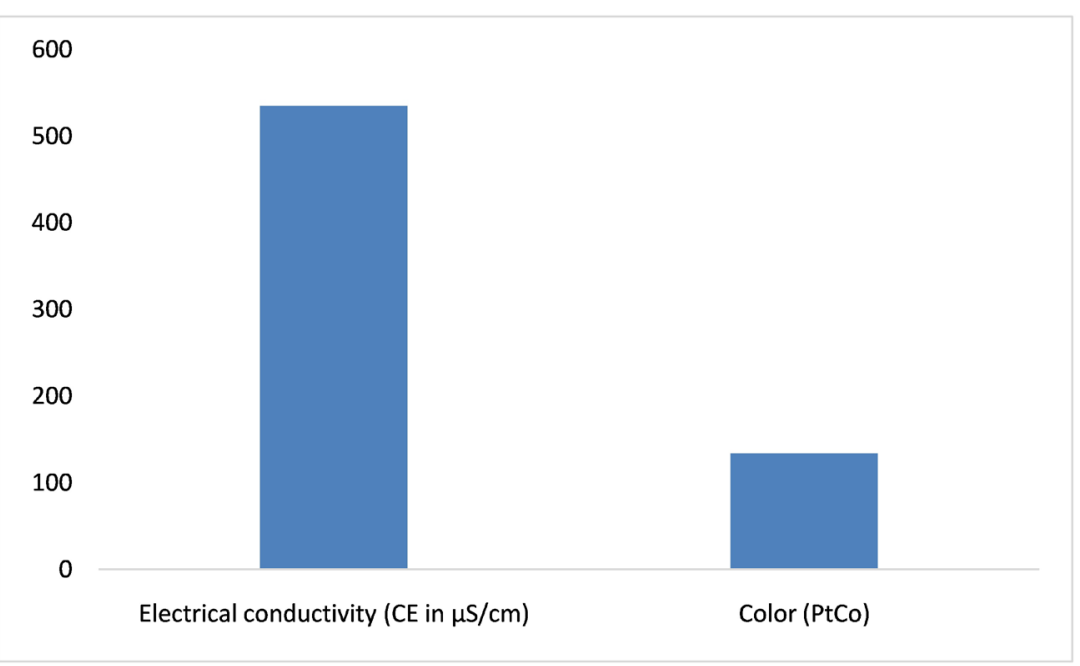

Figure 4. Electrical conductivity and color values of the water from the Hounhouè.

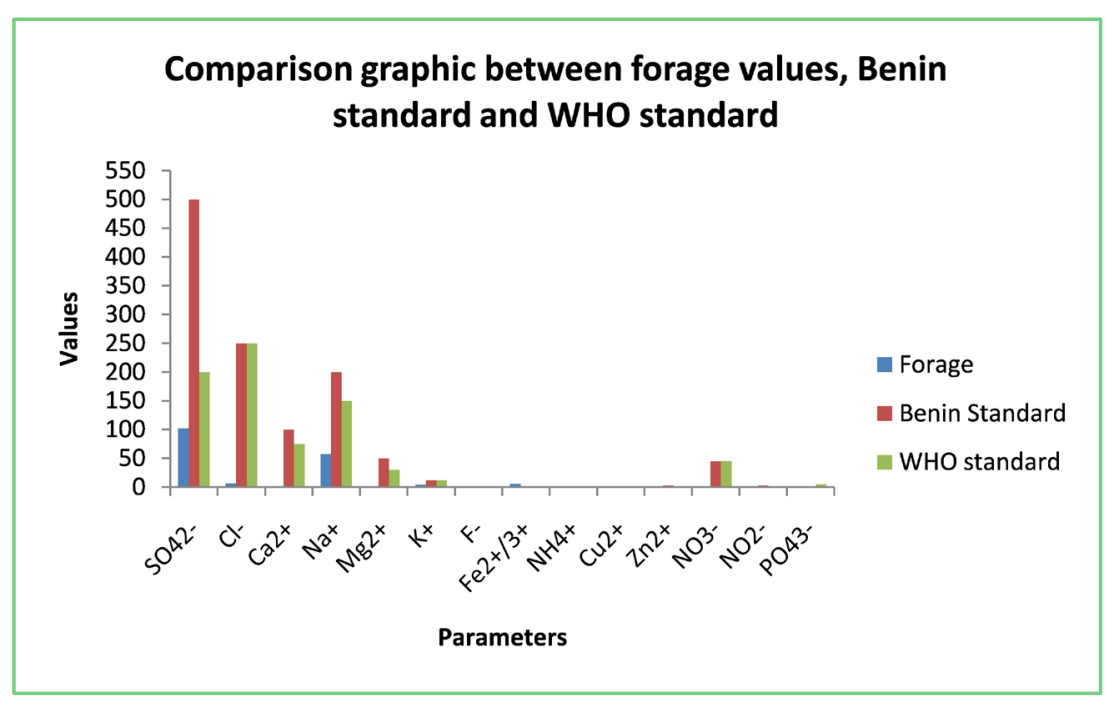

Figure 5. Comparison between forage values, Benin and WHO standards. 


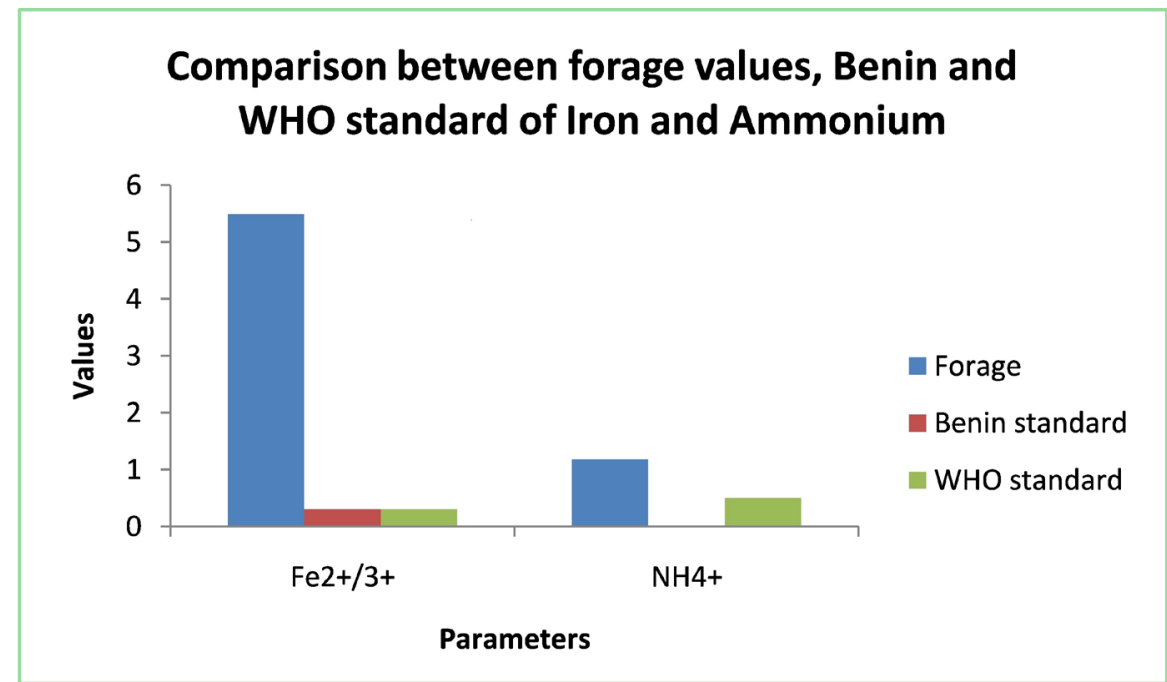

Figure 6. Comparison between forage, Benin and WHO standard of Iron and Ammonium

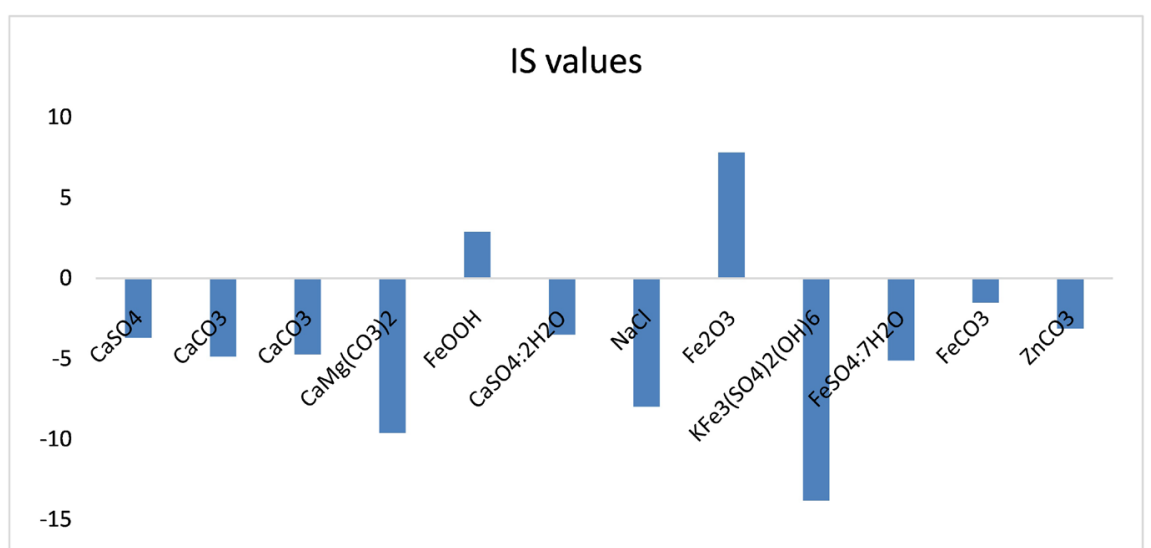

Figure 7. Values of calculated saturation indices.

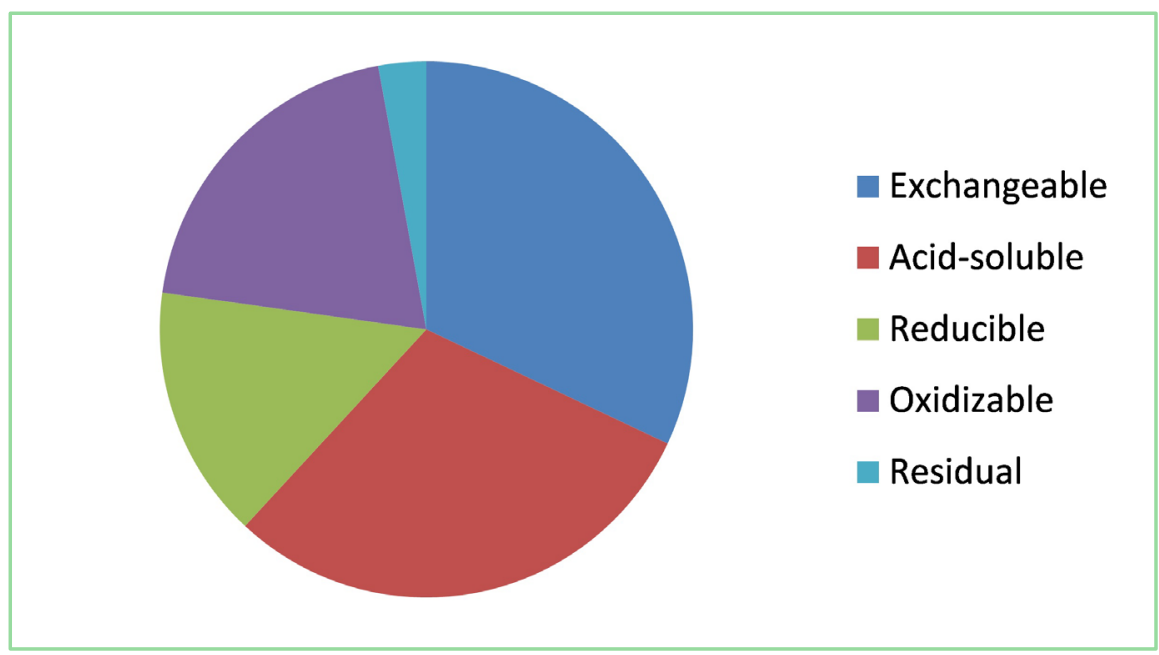

Figure 8. Distribution of iron in the different fractions of the deposit coming from the water of the borehole. 


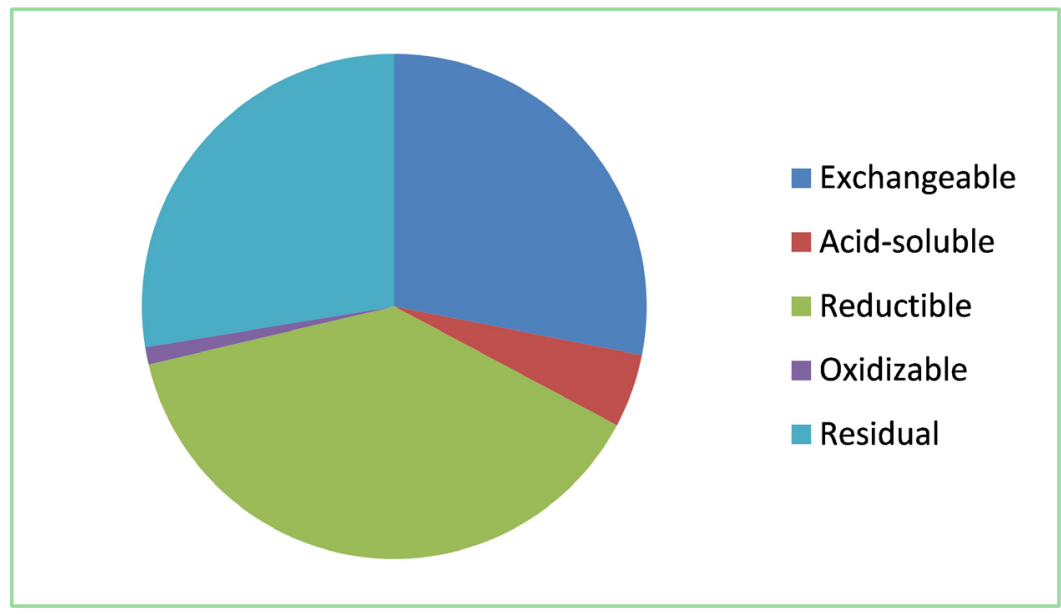

Figure 9. Sequential extractions of copper.

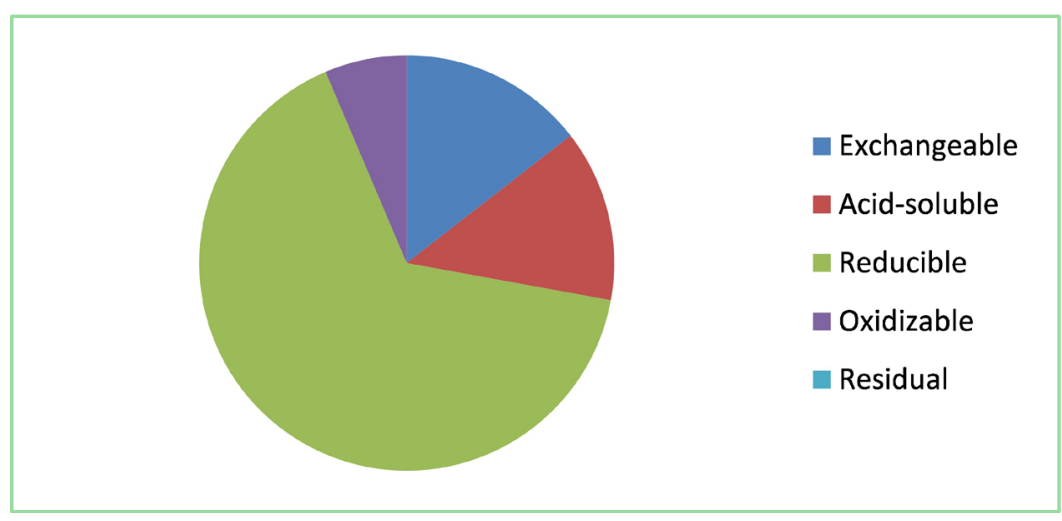

Figure 10. Distribution of zinc in the different fractions of the deposit.

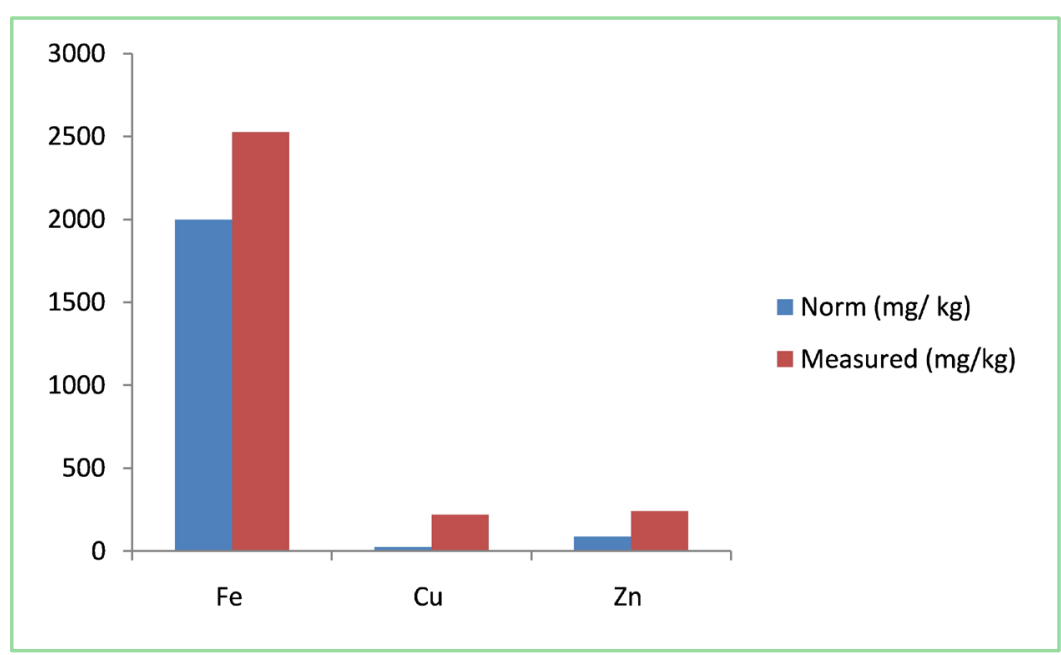

Figure 11. Total contents of metals in the deposits.

Iron is thus the main motor of formation of the deposit which one observes after a few hours in water of drilling. Its deposit also makes it possible to eliminate part of copper and zinc in water. 


\section{Discussion}

Works of this study resulted in holding discussions on the physicochemical parameters, on the thermodynamic evaluation of the water of drilling of Hounhouè, on the speciation of the metal traces elements and on the elimination of iron in water.

\section{$>$ Physico-chemical parameters}

Temperature value recorded during our study $\left(29.3^{\circ} \mathrm{C}\right)$ is lower than the value authorized by the standard of the WHO which is $30^{\circ} \mathrm{C}$. Rodier (1984) [10] quoted that the average temperature of water is $30^{\circ} \mathrm{C}$ in the wet tropical zone. It is also lower to the average temperature, which is $31.95^{\circ} \mathrm{C}$, obtained for ten drillings of the Area of Eastern Logone in Chad [11].

But it is high compared to the relatively stable and fresh temperatures of two sources Ain LOURA and Ain SFA in Algeria where the temperatures are respectively $17.73^{\circ} \mathrm{C}$ and $17.5^{\circ} \mathrm{C}$ [12]. Let us note that a higher temperature with $25^{\circ} \mathrm{C}$ supports the accelerated growth of thus involving micro-organisms unpleasant tastes and odors [13].

Determination of $\mathrm{pH}$ is important: it conditions the calco-carbonic equilibrium and the aggressivity of water [14]. The $\mathrm{pH}$ recorded at the water of the borehole is not up to standard. The $\mathrm{pH}$ value measured in this water is 6.11 thus revealing its acidity. It is lower than the $\mathrm{pH}$ obtained at Grand-Popo in Benin [15] and at the Ain Regrag and Ain Sidi Bouali sources in the Sefrou region of Morocco [16].

The conductivity of studied water, value $535 \mu \mathrm{S} / \mathrm{cm}$, is definitely lower than the Beninese standard which is $2000 \mu \mathrm{S} / \mathrm{cm}$. This value indicates an average retention of the water of drilling in various minerals.

The values of the ions such as sodium, calcium, potassium, fluoride, magnesium, chloride, sulphate, nitrate and nitrite, as well as copper and zinc obtained in the water of drilling are all in conformity with the standards of WHO.

The iron obtained in the water of drilling indicated $5.49 \mathrm{mg} / \mathrm{L}$ of concentration. This high value of iron is comparable with those obtained by Oga et al., (2009), [17] for water of the aquifers of fractures in the area of Tiassale in Ivory Coast which vary from 1.38 to 8.75 . Indeed, the iron excess involves deposits reddish in the conduits and of tasks on the linens and medical. On health, it affects several organs of human such as heart, liver, pancreas, bones and articulations [18].

Ammonium, like iron, had a higher value than the WHO standard. It would come from the reaction of minerals containing iron with nitrates. Better known in the form of ammonium chloride, it is not really dangerous for health.

\section{$>$ Thermodynamic evaluation of drilling water}

From the different values obtained from the Hounhouè drilling water analyzes, it appears that the type of facies encountered in the zone is sulphated sodic. These elements (sulphate and sodium) are the most dominant, therefore those characterizing the water of the borehole. They may vary in content depending 
on the season, the depth and location of the structure, and the geology of a region [19]. Elements metals trace studied in borehole water could result from an alteration or leaching of a layer in contact with water, adsorption and ion exchange.

Supersaturation of the water of drilling with respect to Goethite $(\mathrm{FeOOH})$ and Hematite $\left(\mathrm{Fe}_{2} \mathrm{O}_{3}\right)$ implies that these phases conditions the formation or not of analyzed deposit. Goethite is the most widespread iron oxy-hydroxide in the grounds from its great stability. It is thus present at all the latitudes on our sphere, in temperate zone, wet and cold [20]. Goethite gives a brown-yellow color to the pedological profiles and can be concentrated locally in concretions. Its forms either by dissolution of compounds carrying iron (II) (silicates, carbonates or sulphides of iron) involving the release of iron which is oxidized in goethite in an oxic medium or by transformation of the ferrihydrite into goethite.

The high iron concentration obtained in the water as well as in the precipitate analyzed is in line with the values obtained for groundwater hydrochemistry in the region of Adiaké (southeastern coast of Ivory Coast) [21]. This result is also in line with the results of Ahoussi et al., (2013) [22] who claim that the high iron content obtained in the boreholes is attributed to the geological formations of the region. Abundance of precipitation causes a very intense alteration and dissolves primary minerals from the source rock by hydrolysis. This alteration results in the individualization of the metal oxides and also the release of residual quartz elements in abundance. Thus, high concentration of iron obtained in the water could be due to the phenomenon of dissolution and/or leaching caused by water as it passes through the ocher-ocher coarse sand layer.

The aquifer's water is thus strongly found mineral-bearing. The iron excess involves deposits reddish in the conduits and of tasks on the linens and medical. On health, it affects several organs such as heart, liver, pancreas, bones and articulations [18] [23]. It thus gives rise to many evils like cirrhosis, diabetes, cancer of liver, osteoarthritis.

Sodium and the sulphate found in strong concentration, and characterizing the type of water of the drilling of Hounhouè could come from the dissolution of the aquiferous rock.

\section{Speciation of the Metal Elements Traces (iron, copper and zinc)}

Precipitate resulting from water of the drilling is strongly rich in trace metallic elements. All the three analyzed elements are found with higher concentrations compared to the French values guides for the contents of metals in sediments.

Unlike Luoma and Rainbow (2008) [24] who claim that based on several studies in the environment, copper is known for its exceptional affinity for organic matter, copper in our case rests mainly on the reducible fraction. It is therefore mainly bound to oxides of iron, aluminum and manganese, weakly crystalline or amorphous. These are elements controlling the copper in the drilling water of Hounhouè. It also has more affinity for exchangeable and residual fractions than for the two other fractions. 
Like copper, zinc is strongly bound to iron oxides. It results from our study that the precipitates obtained are due to iron oxides; and this oxide retains copper and zinc: this consolidates the results obtained with PHREEQC software. Indeed, the supersaturation of the water of the drilling with respect to Goethite $(\mathrm{FeOOH})$ and Hematite $\left(\mathrm{Fe}_{2} \mathrm{O}_{3}\right)$ causes presence of copper and zinc in the iron's deposition. However, zinc has no affinity for the residual fraction. This would mean that the zinc contained in the precipitates is not related to the geochemical background. Its presence is due to alteration because the human impact can't be considered in our case. It nevertheless admits stronger relationships respectively in the oxidizable, acid-soluble and exchangeable fractions.

Iron speciation in this drilling water showed high values at all fractions. The exchangeable fraction of iron is needed with $32 \%$. It is also strongly bound with carbonates, organic matter, aluminum and manganese. Of all the fractions, the residual fraction (bound to silicates) is that showing a small proportion. This indicates that the exchangeable fraction is the main factor impacting the behavior of iron in the Hounhouè drilling water. But the exchangeable fraction is the one that presents more risk for water.

Considering the fractions obtained for the fractionation of the three metals, they can be classified into two large phases: the residual phase and the non-residual phase composed of reducible, oxidizable, acid-soluble and exchangeable fractions. The non-residual phase includes elements that can interact with their environment, as they are potentially considered available for the environment and living organisms. Therefore, the mobility and toxicity of metallic trace elements are related to their proportions in this phase [25]. Similarly, the fractions of the non-residual phase are exchangeable and acid-soluble fractions. There is more extractable when physicochemical conditions change [26] [27]. In our study, copper and zinc are more related to iron and the exchangeable fraction of the latter is the most important: therefore the deposits from drilling water, made of iron, represent a risk of contamination of iron water, zinc and copper.

The various fractions obtained at the time of the speciation of the deposit, compared with the mineral phases obtained in PHREEQC made it possible to deduce from it that Goethite and Hematite are represented by the reducible fraction (connection with oxides) and possibly by the exchangeable fraction (connection nonspecific and practitioner exchanges to surface). Iron is thus the main motor of formation of the deposit which one observes after a few hours in water collected of drilling and the terminals fountains of Hounhouè in the District of Dêkin. Its deposit also makes it possible to eliminate part of copper and zinc in water.

\section{Method of elimination of iron in water}

From all that precedes, to deal with the deposit amounts eliminating Goethite and Hematite from groundwater. Such a treatment can be done by decreasing the $\mathrm{pH}$ of water using acid solution. However, a study must be made to identify 
an inoffensive acid for body and to find the effective dose. But the consequence of such a treatment would be to release the copper and zinc retained by Goethite and Hematite in water. The best treatment will thus consist in making form the precipitates quickly and effectively while allowing Goethite and Hematite to retain the more elements metal traces.

\section{Conclusion}

This study made it possible to evaluate groundwater contamination of Hounhouè's borehole in the District of Dêkin, City of Dangbo in southern Benin by the MTE ( $\mathrm{Cu}, \mathrm{Fe}$ and $\mathrm{Zn})$. In drilling water, copper and zinc have values that meet the standards of water potability. On the other hand, the value of iron in water exceeds the standards. With the exception of the residual fraction of zinc that was not found in the deposit collected, all the others fractions of this element and the two other metals are present with varying concentrations. However, the copper, iron and zinc contents in the deposits are higher than the French guideline values. This contamination is due to the contact of the water with the mineralization present in the geological formations.

\section{Conflicts of Interest}

The authors declare no conflicts of interest regarding the publication of this paper.

\section{References}

[1] Lagnika, M., Moudachirou, I., Jean-Pierre, C., Valentin, W. and Nestor, G. (2014) Physico-Chemical Characteristics of Well Water in the Municipality of Pobè (Benin, West Africa). Journal of Applied Biosciences, 79, 6887-6897. https://doi.org/10.4314/jab.v79i1.13

[2] UNICEF and WHO (2015) Progress on Sanitation and Drinking Water-2015 Update and MDG Assessment. 90 p.

[3] Kelome, N., Chouti, W., Lawani, R. and Olou, P. (2018) Quality of Drinking Water in the Town of Manta in Benin Republic. European Scientific Journal, 14, 188-203.

[4] Fekraoui, A. (2007) Geochemical Characteristics of the Geothermal Waters of the Oran Region. Review of Renewable Energies CER'07 Oujda. 75-80.

[5] Gokgoz, A., Yilmazli, I.E., Gungor, I. and Yavuzer, I. (2010) Hydrogeology and Environmental Study at the Karahayit Geothermal Field (Western Turkey). Proceedings World Geothermal Congress, Bali, 25-29.

[6] Houti, A., Fikri, B., El Ouali, L., Zbadi, L. and Rachiq, S. (2014) Physicochemical and Bacteriological Quality of Three Spas in the Regions of Fez, Morocco. Africa Science, 10, 158-168.

[7] Rodier, J., Legube, B. and Merlet, N. (2009) Water Analysis (Natural Waters, Wastewater, Seawater). 9th Edition, Dunod Edition, Paris.

[8] Tessier, A., Campbell, P. and Bisson, M. (1979) Sequential Extraction Procedure for the Speciation of Particulate Trace Metals. Analytical Chemistry, 51, 844-851. https://doi.org/10.1021/ac50043a017 
[9] Degbey, C., Makoutode, M., Fayomi, B. and De Brouwer, C. (2010) The Quality of Drinking Water in a Professional Environment in Godomey in 2009 in Benin, West Africa. J. Int. Santé. Trav, 1, 15-22.

[10] Rodier, J. (1984) Water Analysis (Natural Waters, Wastewater, Seawater). 7th Edition, Dunod Edition, Paris, 177.

[11] Maoudombaye, T., Ndoutamia, G., Seid Ali, M. and Ngakou, A. (2015) Comparative Study of the Physico-Chemical Quality of Well Water, Boreholes and Rivers Consumed in the Doba Oil Basin in Chad. Larhyss Journal, No. 24, 193-208.

[12] Tir, E., Deche, M., Bounouira, Y. and Chedad, A. (2017) Physico-Chemical and Microbiological Quality of the Water from the Sources of TISSEMSILT Commune "Case of Ain LOURA and Ain SFA". Larhyss Journal, No. 29, 111-119.

[13] Tardat-Henry, M. (1992) Water Chemistry. Ed. Le griffon d'argile. 537 p.

[14] Gartet, A., Gartet, J. and Garcias, C.C. (2001) Hydrochemistry of Water, Specific Dissolution and Salinity of Rivers in the Basin of the Wadi Lbène, Papeles de geographia, 34, 146-161.

[15] Makoutode, M., Assani, A.K., Ouendo, E.-M., Agueh, V.D. and Diallo, P. (1999) Quality and Method of Management of Well Water in Rural Benin: Case of the Sub-Prefecture of Grand-Popo. Medicine of Black Africa, 46.

[16] Nechad, I., Fadil, K. and Fadil, F. (2014) Physicochemical Quality of Ain REGRAG and Ain SIDI BOUALI Springs in the SEFROU Region (MOYEN ATLAS, MAROC). Larhyss Journal, 20, 127-146.

[17] Oga, M., Theophile, L., Theodore, K., Nagnin, S., Mahaman, B., Dongo, K. and Franck, G. (2009) Chemical Characterization of the Waters of Fracture Aquifers: Case of the Tiassalé Region in Côte d'Ivoire. European Journal of Scientific Research, 31, 72-87.

[18] CDU-HGE (2012) Abreged Gastro-Etrology Abstracts. 2nd Edition, Part "Knowledge", Editions Elsevier-Masson.

[19] OBAKIR (2014) Sheet 12, Manganese and Iron: Groundwater Quality. Water Master Plan Diagnosis.

[20] McBride, M. (1994) Environmental Chemistry of Soils. Oxford University Press Inc., New York, $406 \mathrm{p}$.

[21] Eblin, S., Soro, G., Soro, G., Sombo, P., Aka, N. and Kambiré, O. (2014) Hydrochemistry of Groundwater in the Adiake Region (South East of Ivory Coast). Larhyss Journal, 17, 193-214.

[22] Ahoussi, K.E., Koffi, Y.B., Kouassi, A.M., Soro, G. and Biemi, J. (2013) Hydrochemical and Microbiological Study of Mountainous Spring Waters of the Ivory Coast: Case of Mangouin-Yrongouin Village (Biankouman Sub-Prefecture). Journal of Applied Biosciences, 63, 4703-4719.

[23] Markus, H. (2011) Hemochromatosis. Forum Med Suisse, 11, 755-758.

[24] Luoma, S. and Rainbow, P. (2008) Metal Contamination in Aquatic Environments. Cambridge University Press, Cambridge, 129-141.

[25] Salomons, W. and Forstner, U. (1980) Trace Metalanalysis on Polluted Sediments. II: Evaluation of Environmental Impact. Environment Technology Letters, 1, 506-517. https://doi.org/10.1080/09593338009384007

[26] Ma, L.Q. and Rao, G.N. (1997) Chemical Fractionation of Cadmium, Copper, Nickel and Zinc in Contaminated Soils. Journal of Environmental Quality, 26, 259-264. https://doi.org/10.2134/jeq1997.00472425002600010036x 
[27] Leleyter, I. and Probst, J.I. (1999) A New Sequential Extraction Procedure for the Speciation of Particulate Trace Elements in River Sediments. International Journal of Environment Analytical Chemistry, 73, 109-128.

https://doi.org/10.1080/03067319908032656 